\title{
Assessing the Parasitic Burden in a Late Antique Florentine Emergency Burial Site
}

\author{
Kévin Roche ${ }^{1,2, *}$, Elsa Pacciani ${ }^{3}$, Raffaella Bianucci ${ }^{4,5,6}$, Matthieu Le Bailly ${ }^{2, *}$ \\ 'University of Bordeaux Montaigne, CNRS UMR 5607 Ausonius, Maison de I'Archéologie, Domaine universitaire, 8 esplanade des Antilles, 33607 \\ Pessac cedex, France; 'University of Bourgogne Franche-Comté, CNRS UMR 6249 Chrono-Environment, 16 route de Gray, 25030 Besançon \\ cedex, France; '3Soprintendenza Archeologia, Belle Arti e Paesaggio of Firenze, Pistoia and Prato, Italy; ${ }^{4}$ Legal Medicine Section, Department of \\ Public Health and Paediatric Sciences, University of Turin, C.so Galileo Galilei, 22, 10126 Torino, Italy; ${ }^{5}$ Warwick Medical School, Biomedical \\ Sciences, University of Warwick, Coventry, 4CV 7 AL, United Kingdom; ${ }^{6}$ ADES (UMR 7268), Laboratoire d'Anthropologie bio-culturelle, Droit, \\ Éthique \& Santé (Adés), Faculté de Médecine de Marseille, 51 Boulevard Pierre Dramard, France
}

\begin{abstract}
Excavation (2008-2014) carried out under the Uffizi Gallery (Florence, Italy) led to the discovery of 75 individuals, mostly buried in multiple graves. Based on Roman minted coins, the graves were preliminarily dated between the second half of the 4th and the beginning of the 5th centuries CE. Taphonomy showed that this was an emergency burial site associated with a catastrophic event, possibly an epidemic of unknown etiology with high mortality rates. In this perspective, paleoparasitological investigations were performed on 18 individuals exhumed from 9 multiple graves to assess the burden of gastrointestinal parasitism. Five out of eighteen individuals (27.7\%) tested positive for ascarid-type remains; these are considered as "decorticated" Ascaris eggs, which have lost their outer mammillated coat. Roundworms (genus Ascaris) commonly infest human populations under dire sanitary conditions. Archaeological and historical evidence indicates that Florentia suffered a period of economic crisis between the end of 4th and the beginning of the 5th centuries $\mathrm{CE}$, and that the aqueduct was severely damaged at the beginning of the 4th century $\mathrm{CE}$, possibly during the siege of the Goths (406 CE). It is more than plausible that the epidemic, possibly coupled with the disruption of the aqueduct, deeply affected the living conditions of these individuals. A $27.7 \%$ frequency suggests that ascariasis was widespread in this population. This investigation exemplifies how paleoparasitological information can be retrieved from the analysis of sediments sampled in cemeteries, thus allowing a better assessment of the varying frequency of parasitic infections among ancient populations.
\end{abstract}

Key words: Paleoparasitology, ascaris, egg, cemetery, bioarchaeology, emergency burial site, florence, Italy, Late Antiquity

Paleoparasitology is the study of the evolution and of the ecological history of parasitic organisms in humans and other animals [1]. Depending on the species, gastrointestinal worms produce eggs ranging in size from $\sim 30 \mu \mathrm{m}$ to $\sim 160 \mu \mathrm{m}$ [2]. On account of their median coat, composed of chitin, sclerotin and/or keratin, the eggs can be recovered after several millennia [3-6].

In archaeological contexts, paleoparasitology helps scholars to answer questions relating to the way of life of ancient populations: their sanitary conditions, food habits, waste management, or the use of space in archaeological sites. In a broader

\footnotetext{
- Received 30 August 2019, revised 25 September 2019, accepted 30 September 2019. *Corresponding authors (kevroch@gmail.com; matthieu.lebailly@univ-fcomte.fr) (c) 2019, Korean Society for Parasitology and Tropical Medicine This is an Open Access article distributed under the terms of the Creative Commons Attribution Non-Commercial License (http://creativecommons.org/licenses/by-nc/4.0) which permits unrestricted non-commercial use, distribution, and reproduction in any medium, provided the original work is properly cited.
}

perspective, the study of ancient parasites leads to a better understanding of the evolution of the human-pathogen relationship [7]. Traditionally, paleoparasitology focuses mainly on the analysis of coprolites from latrines and sewers [8]. Less attention has been paid to the analysis of sediments collected in cemeteries and necropolises. Recent research has shown that cemeteries and large bio-anthropological collections provide scholars with a more refined understanding of the paleo-epidemiological dynamics of parasitic infections [9]. Here, we report a new evidence of ascariasis in a sample of the Florentine population from Late Antiquity.

Florentia (ancient Florence) was founded at the end of the first century CE. Surrounded by walls, the city was a pan-Mediterranean urban trade center throughout the Imperial Age [10]. Florence acted as a crossroads through which imported goods transited to supply the army and the metropolis (Rome), as well as other major cities [11]. The macro-economic system 
ensured a generalized well-being and gave rise to local microeconomies. During the second century CE (Hadrianic Age, 117-138 CE), at an urban level, Florence was a wealthy Roman city [12]. However, in Late Antiquity (end of the 4th and beginning of the 5th centuries), Florence underwent a profound economic crisis due to a decrease in imports. This decline was partially balanced out by the development of local economies [11]. In 406 CE, Florence was sieged by the Goths led by Radagaisus. Although the Barbarian army was unable to penetrate the city and was defeated by the Master-General Stilicho in the Battle of Faesulae (August $406 \mathrm{CE}$ ), the siege had dramatic consequences for the Florentine population [13]. Based on archaeological evidence, between the end of the 4th century and beginning of the 5th centuries CE (possibly during the siege of the Goths), the aqueduct was severely damaged and was not repaired. These events coincided with period of decadence [11].

Archaeological excavations (2008, 2013, and 2014) led to uncover a large sepulchral area under the basement of the eastern wing of the Uffizi Gallery (Florence, Italy). Aside from single graves, 14 multiple graves were excavated and a total of 75 individuals were exhumed. In multiple graves, up to ten individuals had been deposed simultaneously (Fig. 1). Taphono-
Table 1. Paleoparasitological observations among 18 individuals. Five showed remains of Ascaris sp.

\begin{tabular}{lclc}
\hline Lab sample ID & $\begin{array}{c}\text { Tomb/ } \\
\text { Individual ID }\end{array}$ & Localization & $\begin{array}{c}\text { Ascaris sp./ } \\
\text { Ascarid }\end{array}$ \\
\hline UFF17 P1 & T8 IND C & Lumbar vertebrae & yes \\
UFF17 P2 & T8 IND E & coccyx & - \\
UFF17 P3 & T8 IND E & pelvis & - \\
UFF17 P4 & T9 IND A & pelvis & yes \\
UFF17 P5 & T9 IND C & sacrum & yes \\
UFF17 P6 & T9 IND E & pelvis & - \\
UFF17 P7 & T9 IND E & sacrum & - \\
UFF17 P8 & T10 IND C & pelvis & - \\
UFF17 P9 & T16 & pelvis & - \\
UFF17 P10 & T17 IND B & pelvis & - \\
UFF17 P11 & T18 IND B & pelvis & - \\
UFF17 P12 & T18 IND C & pelvis & - \\
UFF17 P13 & T18 IND D & pelvis & - \\
UFF17 P14 & T19 IND A & pelvis & - \\
UFF17 P15 & T19 IND B & pelvis & - \\
UFF17 P16 & T19 IND C & pelvis & - \\
UFF17 P17 & T19 IND D & pelvis & - \\
UFF17 P18 & T20 IND C & pelvis & - \\
UFF17 P19 & T22 IND A & pelvis & yes \\
UFF17 P20 & T22 IND A & coccyx & - \\
UFF17 P21 & T22 IND B & coccyx & yes \\
UFF17 P22 & T22 IND B & sacrum & \\
\hline & & & yes \\
\hline
\end{tabular}

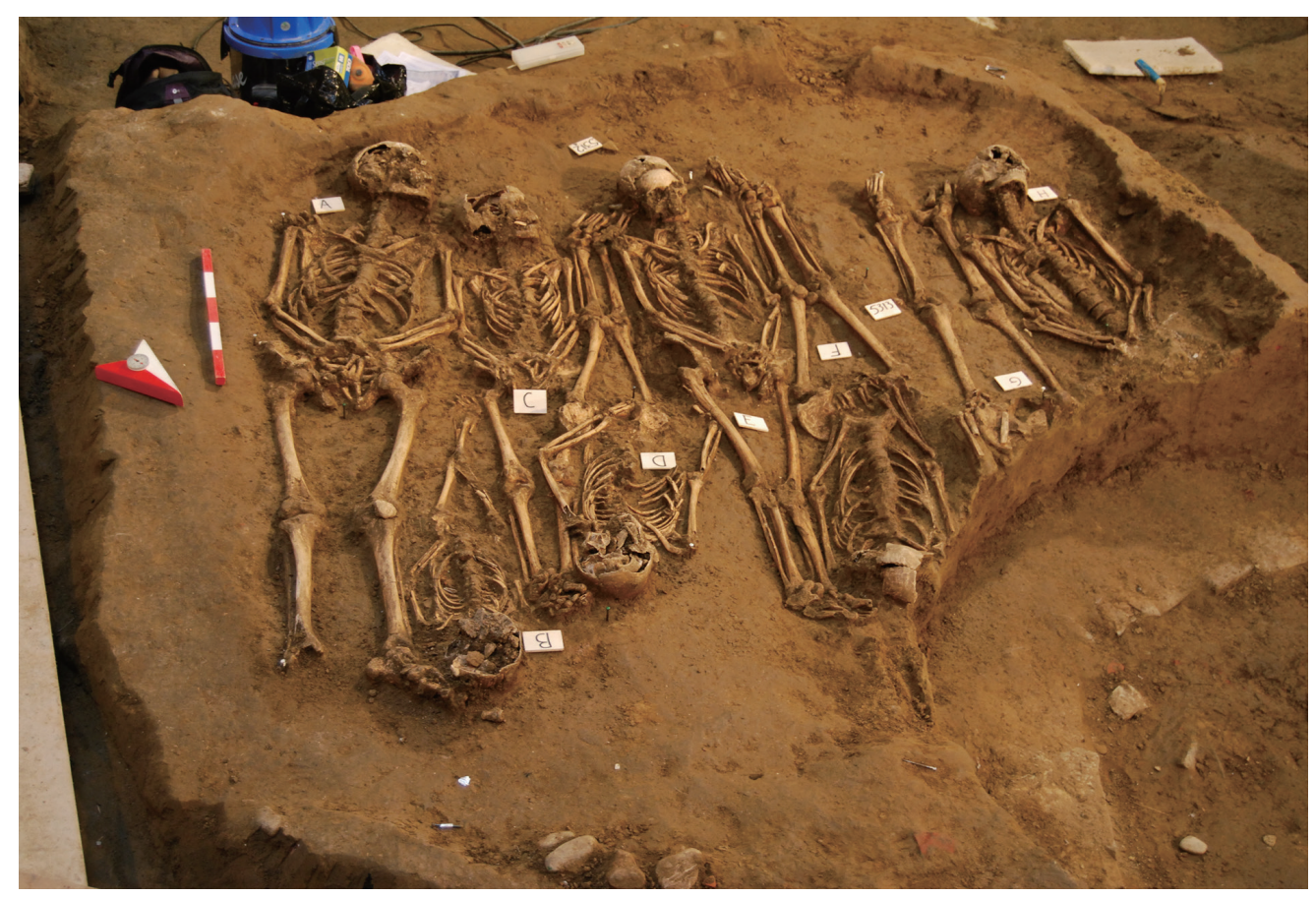

Fig. 1. Pit grave T9 (Uffizi Gallery, Florence) containing 8 aligned individuals deposed simultaneously. The bodies were closely joined, with alternating orientation and diversified position of the upper limbs. 
my showed that this area did not correspond to an ordinary cemetery but to an emergency burial site dug out of the city walls possibly during an epidemic of unknown etiology [14]. The burial site was preliminarily dated between the second half of the 4th and the beginning of the 5th centuries $\mathrm{CE}$, based on minted coins associated with some of the skeletons.

Twenty-two samples of sediment (100 g each) associated with 18 individuals were systematically collected from the pelvic area of each skeleton in order to analyze the remnants of their intestinal contents (Table 1). We applied the RHM protocol (for Rehydration - Homogenization - Microsieving) to extract microscopic eggs of gastrointestinal worms from the sediments. This method is widely used in paleoparasitology as it is propitious to the successful recovery of the parasitic diversity contained in the analyzed specimens [15]. For each sample, 5 $\mathrm{g}$ of material were rehydrated for 1 week in a $50 \mathrm{ml}$ solution of $0.5 \%$ aqueous trisodium phosphate (TSP) and $50 \mathrm{ml}$ of $5 \%$ glycerinated solution. A few drops of $10 \%$ formalin solution were added to circumvent organic pollution. In order to separate parasitic specimens from the surrounding sediments, samples were then crushed in a mortar and sonicated in an ultrasonic device for $1 \mathrm{~min}$ at 50/60 Hz. Lastly, samples were strained through a microsieving column consisting of 315, 160,50 , and $25 \mu \mathrm{m}$ meshes. Only the residues from the 50 $\mu \mathrm{m}$ and $25 \mu \mathrm{m}$ meshes were kept, as they contain the whole putative parasitic diversity, with eggs ranging from 30 $\mu \mathrm{m}$ to 160 $\mu \mathrm{m}$. After $24 \mathrm{hr}$ sedimentation, samples were ready for microscopic analysis. Twelve slides $(22 \times 22 \mathrm{~mm})$ were read for each sample, consisting of 6 slides from the $50 \mu \mathrm{m}$ sieve, and 6 slides from the $25 \mu \mathrm{m}$ sieve.

Among the 22 collected samples, 186 ascarid-type eggs were identified in 6 positive samples associated with 5 individuals (Table 1; Fig.2). Ninety-six percent (96\%) of the eggs (179 out of 186 eggs) were identified in one sample exhumed from Tomb 9 (UFF17 P5, Tomb 9 individual C, sampled area: sacrum), and some of them still harbored remnants of the outer shell. In the remaining 5 samples (Tombs 8, 9, 22), the number of observed eggs per sample varied from 1 to 3 . Hence, a $27.7 \%$ frequency of parasitic remnants was identified in the examined archaeological population (T8, T9, T22).

Ascarid-type specimens are commonly observed in archaeological contexts. They consist of oval specimens, roughly 60-70 $\mu \mathrm{m}$ long and 40-50 $\mu \mathrm{m}$ wide, with one clearly identifiable thick and smooth shell. Ascarid-type specimens are often observed nearby eggs of roundworms belonging to the genus Ascaris, characterized by a thick shell and a bumpy mammillated outer layer. Ascarid-type specimens are attributed by consensus to "decorticated" Ascaris eggs, which have lost their outer mammillated coat [16]. It is generally admitted that this genus consists of 2 species, namely A. suum and A. lumbricoides, which
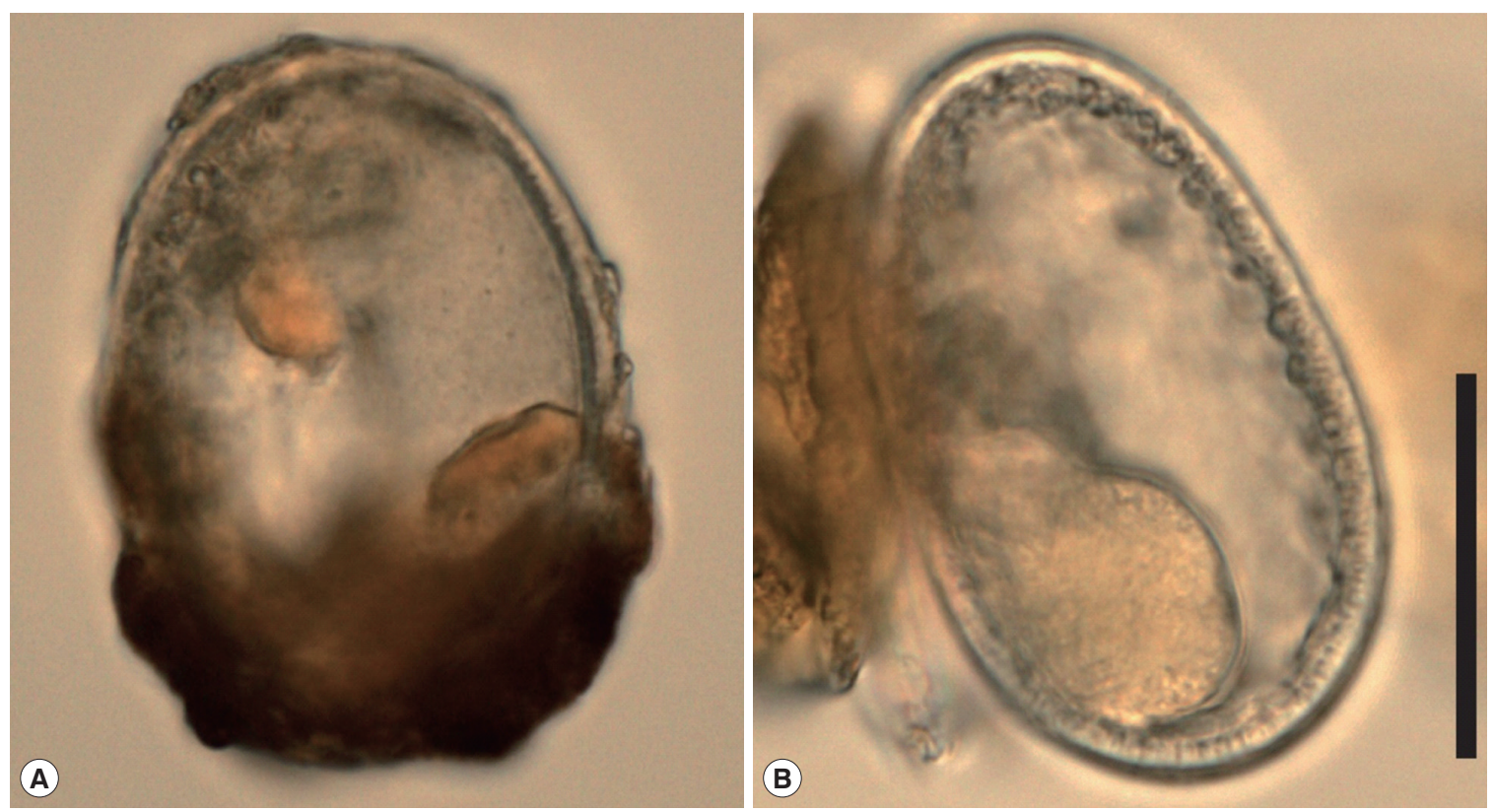

Fig. 2. Ascaris sp. eggs. (A) the lower part is still coated with the outer shell (dark brown). (B) decorticated egg (morphotype "ascarid") with preserved inner content in the lower part. Scale: $50 \mu \mathrm{m}$. 
infest pigs and humans, respectively. The eggs produced by these 2 taxa are identical, and no specific discrimination based exclusively on morphological traits can be performed. Moreover, molecular data tend to recognize only 1 species infecting both human and pig, namely A. lumbricoides [17]. In our case, because of the archaeological context and sampling methods, an attribution to the human species is anyway more likely.

A wide range in the number of observed eggs per sample was recorded at Uffizi, from one egg (UFF17 P4, UFF17 P19, UFF17 P21, UFF17 P22) to 179 eggs (UFF17 P5). This difference may be the result of a different parasitic load. However, differences may be also attributed to the ecology of the parasite. Although a female A. lumbricoides can produce around 200,000 eggs per day and several adult worms may infest a single person, the production of eggs varies on a daily basis and is not continuous.

Since this was an emergency burial context, burial conditions were probably stable over time. It seems reasonable to surmise that the number of counted eggs reflects the infection rates per individual. However, in the absence of eggs per gram count (EPG), this assumption remains highly speculative. EPG was not performed since this was an analysis of sediments (and not of coprolites). In sediments, the intestinal contents leach and dilute. If the distribution pattern observed in the Uffizi archaeological population was truly representative of differential infection rates, it would be consistent with a typical aggregate pattern seen in parasite ecology, where a minority of the infected population hosts the majority of the parasite population [18].

Several parasite species have been detected in Italy through systematic diagnosis under light microscopy, namely Trichuris sp., Capillaria sp., unidentified strongyle-like nematodes, Dicrocoelium sp., Opistorchis sp., Fasciola sp., Taenia sp., and Diphyllobothrium sp. [19-24] (Table 2). More specifically, Ascaris sp. was previously detected in a Roman Period sediment core from Ostia [22], and from medieval pits excavated in Parma [24]. The present study identifies a strict association of Ascaris sp. with human burials for the first time in the Italian Peninsula. This association sheds light on the frequency of ascariasis in an ancient Late Antique population.

The microparasitic record in ancient Italy reveals the presence of Protozoa, namely Plasmodium falciparum, Entamoeba histolytica and Leishmania infantum. E. histolytica was detected in a Roman period sediment core [25], whereas Plasmodium falciparum was identified in the dental pulp of 2 Roman Period individuals from the settlements of Velia (Salerno, Campania) and Vagnari (Apulia) [26], and in human bones from the 5th century. Lugano CE [27].

For later periods, Malaria was also detected in the skeletal remains of members of the Renaissance Medici family in Florence from the 16th century $[28,29]$. Through paleoimmunological (Wetern Blotting SDS-PAGE) and paleomolecular analyses, Leishmania infantum was also identified in the bony remains of Eleonora di Toledo (1519-1562), the wife of Grand Duke Cosimo I de' Medici [30].

Our data provide evidence that the Late Antique individuals buried beneath the Uffizi Gallery were plagued by ascariasis. This parasitism is acquired via fecal-oral transmission, which consists in the ingestion of food and/or water contaminated by human and/or animal stools [31]. Nowadays, endemic ascariasis is almost inexistent in the Western World, but it still has a dramatic impact on the lives of the poor. In the 90s, its

Table 2. Paleoparasitological data in Italy

\begin{tabular}{|c|c|c|c|c|c|}
\hline Site & Period & Sampling context & Helminths & Protozoa & Reference \\
\hline Italy & Roman & Latrines & Trichuris sp. & & [19] \\
\hline Pompei & 1st c. CE & Pipes & Trichuris sp. & & {$[20,21]$} \\
\hline Ostia & Roman & Sediment core & $\begin{array}{l}\text { Ascaris sp., Capillaria sp., Strongyle type eggs, } \\
\text { Dicrocoelium sp., Opisthorchis sp., Fasciola sp. }\end{array}$ & & [22] \\
\hline Parma & $\begin{array}{l}\text { 3rd-2nd c. BCE } \\
\text { 10th-12th c. CE }\end{array}$ & $\begin{array}{l}\text { Layers } \\
\text { Pits }\end{array}$ & $\begin{array}{l}\text { Trichuris sp. } \\
\text { Ascaris sp., Trichuris sp., Diphyllobothrium sp., } \\
\text { Dicrocoelium sp., Capillaria sp., Taenia sp. }\end{array}$ & & $\begin{array}{l}{[23]} \\
{[24]}\end{array}$ \\
\hline Velia & 1st-2nd c. CE & Human bone & & Plasmodium falciparum & [26] \\
\hline Vagnari & 1st-4th c. CE & Human bone & & P. falciparum & [26] \\
\hline Lugano & 5th c. CE & Human bone & & P. falciparum & {$[27]$} \\
\hline Rome & Roman & Sediment core & & Entamoeba histolytica & [25] \\
\hline Pisa & 16th c. CE & Human bone & & $\begin{array}{l}\text { P. falciparum, } \\
\text { Leishmania infantum }\end{array}$ & [28-30] \\
\hline
\end{tabular}


prevalence reached $90 \%$ in the poorest populations of the world [31]. In the second decade of the 21st century, a similar rate of prevalence is still registered in South India and Southwest China $[32,33]$. The infection may cause physical and cognitive growth impairment in children, respiratory symptoms, abdominal pain, vomiting, anemia, diarrhea and intestinal obstruction [31]. Furthermore, ascariasis acts as a dramatic lever in areas of the world where people are exposed to starvation and reinforces the action of other major pathogens such as tuberculosis [34,35]. The bulk of the parasitic burden caused by intestinal worms does not necessarily result in acute conditions, such as deadly pancreatitis due to Ascaris adult worms, for instance. Rather, it is associated with chronic conditions enhancing the compensatory mortality rate (as opposed to the additive mortality rate).

Given the frequency of ascariasis observed in the present study (27.7\%) and the ability of the parasite to survive in the ground for up to 5 years, we surmise that ascariasis was most likely widespread in the analyzed Florentine population sample in Late Antiquity. It is reasonable to suppose that, given the high number of casualties, seemingly linked to an epidemic event, ascariasis had a compensatory effect on mortality rates.

It is impossible to assess whether the Florentine archaeological population was plagued by other chronic parasites due to the poor state of preservation of the eggs and/or the specificity of the analyzed material (sediment with high dilution of the eggs). Based on the parasitic diversity identified in Roman archaeological sites in Italy, they may also have been infested with Trichuris trichiura, another gastrointestinal parasite with a fecal-oral transmission route; this parasite was detected in pipes from Pompeii $[20,21]$. The dysenteric protozoa E. histolytica, previously detected in Roman Period core sediments from Rome, might also have been active, adding other acute pathological conditions to the overall burden of diseases [25]. The same holds true for other pathogens, such as Plasmodium falciparum, recorded in Southern Italy [26] and Tuscany [28]. Co-infections among parasites and bacteria dating back to the Roman Period have also been identified outside Italy [36].

The present study is part of a multidisciplinary project aimed at reconstructing the living conditions of this Late Antique Florentine population. The paleoparasitological investigation shed light on their parasitic burden. Microscopic remains belonging to the Ascarid morphotype and attributed to the species A. lumbricoides were identified in $27.7 \%$ of the analyzed individuals. This parasite, a human infesting nematode, commonly plagues people living in unsanitary conditions and is acquired by the ingestion of contaminated food and water. The archaeological sources indicate that between the 4th and the 5th centuries $\mathrm{CE}$, the Florentine aqueduct was disrupted and was not repaired until a later period. It is highly likely that the people who lived in dire sanitary conditions were infested with different types of gastrointestinal parasites and that comorbidity occurred. Such a parasitic burden may have aggravated any kind of epidemic, leading to high mortality rates.

This investigation exemplifies how paleoparasitological information can be retrieved from the analysis of sediment collected in cemeterial areas. It also argues in favor of a greater integration of systematic paleoparasitological analyses. As shown by a previous study [37], ancient DNA investigations shall be routinely performed in conjunction with microscopic analysis in a growing number of cemeteries in order to gain enhanced insights into ancient parasitic diversity. Lastly, the present study corroborates the current paleoparasitological trend showing that sediments from cemeteries allow for a better approximation of the varying frequency of parasitic infections among ancient populations.

\section{ACKNOWLEDGMENT}

This project benefited of funds from the French National Agency for Research through its program "Investissements d'avenir", referenced as ANR-10-LABX-52.

\section{CONFLICT OF INTEREST}

We have no conflict of interest related to this work.

\section{REFERENCES}

1. Dittmar K, Araújo A, Reinhard K. The study of parasites through time: archaeoparasitology and paleoparasitology. In Grauer AL ed, A Companion to Paleopathology. New Jersey, USA. WileyBlackwell. pp 170-190.

2. Ash LR, Orihel TC. Ash \& Orihel's atlas of human parasitology. 5th ed. Chicago, USA. ASCP Press. 2007, pp 540.

3. Wharton D. Nematode egg-shells. Parasitology 1980; 81: 447.

4. Reinhard KJ. Parasitology as an interpretive tool in archaeology. Am Antiq 1992; 57: 231-245.

5. Smyth J. Introduction to Animal Parasitology. 3rd ed. New York, USA. Cambridge University Press. 1994, pp 569.

6. Peters WL, Taraschewski H, Inge L. Comparative investigations of the morphology and chemical composition of the eggshells 
of Acanthocephala. Parasitol Res 1992; 77: 542-549.

7. Le Bailly M, Maicher C, Dufour B. La paléoparasitologie. Les nouvelles de l'archéologie 2017; 148: 45-49.

8. Appelt S, Drancourt M, Le Bailly, M. Human coprolites as a source for paleomicrobiology. Microbiol Spectr 2016; 4: $\mathrm{PoH}-$ 0002-2014.

9. Hibbs AC, Secor WE, Van Gerven D, Armelagos G. Irrigation and Infection: The Immunoepidemiology of Schistosomiassis in Ancient Nubia. Am J Phys Anthropol 2011; 145: 290-298.

10. De Marinis G, 1996 Firenze: archeologia e storia dell'insediamento urbano. I: Un profilo di sviluppo. In Capecchi G ed, Alle origini di Firenze: dalla preistoria alla città romana. Firenze Italy, Edizioni Polistampa. 1996, pp 36-42 (in Italian).

11. Panella C. Merci e scambi nel Mediterraneo tardoantico, in A. Carandini, L. Cracco Ruggini, A. Giardina (a cura di), Storia di Roma. III: L'età tardoantica. II: I luoghi e le culture. Torino, Italy. Einaudi. 1993, pp 613-697 (in Italian).

12. Cantini F, Cianferoni C, Francovich R, Scampoli E, ArnoldusHuyzendveld A, Baldi A, Belli M, Bruttini J, Buonincontri MP, Caroscio M, Citriniti G, Corbini CA, Degasperi A, Degl'innocenti E, Di Pasquale G, Donnini D, Fornaciari A, Lelli P, Mendera M, Mori Secchi M, Papaccio G, Pecci A, Pignattelli S, Pruno E, Salvini L, Spezi L, Terzani M, Torsellini L, Viglietti C. Firenze prima degli Uffizi : lo scavo di via de' Castellani : contributi per un'archeologia urbana fra tardo antico ed età moderna. Firenze, Italy. All'Insegna del giglio. 2007 (in Italian).

13. Davidsohn R. Storia di Firenze. I: Le origini. Firenze, Italy. Sansoni. 1969, pp 45 (in Italian).

14. Pacciani E, Albertini E, Baldi I, Gori S, Quaglia L. Strategie di emergenza: il seppellimento in corso di una moria di durata imprevedibile. In Nizzo ed, Archeologia e antropologia della morte. 3, Costruzione e decostruzione del sociale: atti del [terzo] incontro internazionale di studi: Roma, Ecole Française - Stadio di Domiziano, 20-22 Maggio 2015. Roma, Italy. Editorial Service System. 2018, pp 185-194 (in Italian).

15. Dufour B, Le Bailly M. Testing new parasite egg extraction methods in paleoparasitology and an attempt at quantification. Int J Paleopathol 2013; 3: 199-203.

16. Garcia LS. Intestinal nematodes. In Garcia LS ed, Diagnostic Medical Parasitology. Washington D.C., USA. ASM Press. 2007, pp 249-292.

17. Leles D, Gardner SL, Reinhard K, Iniguez A, Araújo A. Are Ascaris lumbricoides and Ascaris suum a single species? Parasit Vectors 2012; 5: 42.

18. Camacho M, Araújo A, Morrow J, Buikstra J, Reinhard K. Recovering parasites from mummies and coprolites: an epidemiological approach. Parasit Vectors 2018; 11: 248.

19. Heirbaut E, Jones AKG, Wheeler W. Archaeometry: methods and analysis. In Jansen GCM, Koloski-Ostrow AO, Moormann EM eds, Roman Toilets: Their Archaeology and Cultural History. Leuven, Belgium. Peeters. 2011, pp 7-20.

20. Dubbin AM. Analysis of faecal deposits from Pompeii, Italy: a new source of evidence for ancient diet and urban ecology [dis- sertation]. [Bradford]: University of Bradford; 2003

21. Love M. Analysis of calcareous deposits from the down pipes of first century Pompeii [dissertation]. [Bradford]: University of Bradford, 2007.

22. Dufour B. Synthèse de données et nouvelle contribution à l'étude des parasites de l'époque romaine, et apports méthodologiques de l'extraction des marqueurs au traitement des résultats [dissertation]. [Besançon]: University of Bourgogne Franche-Comté, 2015, pp 337.

23. Bosi G, Mazzanti MB, Florenzano A, N'siala IM, Pederzoli A, Rinaldi R, Torri P., Mercuri AM. Seeds/fruits, pollen and parasite remains as evidence of site function: piazza Garibaldi - Parma (N Italy) in Roman and Mediaeval times. J Arch Sci 2011; 38: 1621-1633.

24. Florenzano A, Mercuri AM, Pederzoli A, Torri P, Bosi G, Olmi L, Rinaldi R, Bandini Mazzanti M. The significance of intestinal parasite remains in pollen samples from Medieval pits in the Piazza Garibaldi of Parma, Emilia Romagna, Northern Italy. Geoarchaeology 2012; 27: 34-47.

25. Le Bailly M, Bouchet F. A first attempt to retrace the history of dysentery caused by entamoeba histolytica. In Mitchell PD ed, Sanitation, Latrines and Intestinal Parasites in Past Populations. Farnham, Burlington. Ashgate. 2015, pp 219-228.

26. Marciniak S, Prowse TL, Herring, Kuch M, Duggan AT, Bondioli L, Holmes EC, Poinar HN. Plasmodium falciparum malaria in 1st2nd century CE southern Italy. Curr Biol 2016; 26: 1220-1222.

27. Sallares R, Gomzi S. Biomolecular Archaeology of Malaria. Anc Biomol 2001; 3: 195-213.

28. Fornaciari G, Giuffra V, Ferroglio E, Gino S. Bianucci R. Plasmodium falciparum immunodetection in bone remains of members of the Renaissance Medici family (Florence, Italy, 16th century). Trans R SocTrop Med Hyg 2010; 104: 583-587

29. Fornaciari G, Giuffra V, Ferroglio E, Bianucci R. Plasmodium falciparum was the "killer" of the Medici, Grand Dukes of Florence. Am J Med 2010; 123: 568-569.

30. Nerlich AG, Bianucci R, Trisciuoglio A, Schönian G, Ball M, Giuffra V, Bachmeier B, Pusch CM, Ferroglio E, Fornaciari G. Visceral leishmaniasis during Italian Renaissance, 1522-1562. Emerg Infect Dis 2012; 18: 184-186.

31. Bourée P, Nozais JP. Ascaridiose In Nozais JP, Datry A, Danis M eds, Traité de Parasitologie Médicale. Paris, France. Pradel. 1999, pp. 409-421 (in French).

32. Savioli L, Albonico M. Soil-transmitted helminthiasis. Nat Rev Microbiol 2004; 2: 618-619.

33. Salam N, Azam S. Prevalence and distribution of soil-transmitted helminth infections in India. BMC Public Health 2017; 17: 201.

34. Rafi W, Ribeiro-Rodrigues R, Ellner JJ, Salgame P. 'Coinfectionhelminthes and tuberculosis'. Curr Opin HIV AIDS 2012; 7: 239244.

35. Van der Zalm MM, van Soelen N, Mandalakas AM, Jacobsen M, Detjen AK, Marx FM, Grewal HM, Cotton MF, Walzl G, Hesseling AC. The effect of deworming on tests of tuberculosis infec- 
tion in children with recent tuberculosis exposure: a randomized controlled trial. Pediatr Infect Dis J 2016; 35: 622-627.

36. Lalremruata A, Ball M, Bianucci R, Welte B, Nerlich AG, Kun JFJ, Pusch CM. Molecular identification of falciparum malaria and human tuberculosis co-infections in mummies from the Fayum depression (Lower Egypt). PLoS One 2013; 8: e60307.

37. Côté NM, Daligault J, Pruvost M, Bennett EA, Gorgé O, Guimaraes S, Capelli N, Le Bailly M, Geigl EM, Grange T. A new highthroughput approach to genotype ancient human gastrointestinal parasites. PLoS One 2016; 11: e0146230. 
